Article

\title{
Assessing Maximum Power Point Tracking Intelligent Techniques on a PV System with a Buck-Boost Converter
}

\author{
Maria I. S. Guerra ${ }^{1} * \mathbb{D}$, Fábio M. Ugulino de Araújo ${ }^{2} \mathbb{D}$, Mahmoud Dhimish ${ }^{3}$ and Romênia G. Vieira $^{1} \mathbb{D}$ \\ 1 Department of Engineering and Technology, Semi-Arid Federal University, Mossoró 59625-900, Brazil; \\ romenia.vieira@ufersa.edu.br \\ 2 Department of Computer and Automation Engineering, Federal University of Rio Grande do Norte, \\ Natal 59078-970, Brazil; meneghet@dca.ufrn.br \\ 3 Department of Electronic Engineering, University of York, York YO10 5DD, UK; \\ mahmoud.dhimish@york.ac.uk \\ * Correspondence: izabel.guerra@ufersa.edu.br
}

Citation: Guerra, M.I.S.; Ugulino de Araújo, F.M.; Dhimish, M.; Vieira, R.G. Assessing Maximum Power Point Tracking Intelligent Techniques on a PV System with a Buck-Boost Converter. Energies 2021, 14, 7453. https://doi.org/10.3390/en14227453

Academic Editor: Frede Blaabjerg

Received: 11 September 2021

Accepted: 9 October 2021

Published: 9 November 2021

Publisher's Note: MDPI stays neutral with regard to jurisdictional claims in published maps and institutional affiliations.

Copyright: (c) 2021 by the authors. Licensee MDPI, Basel, Switzerland. This article is an open access article distributed under the terms and conditions of the Creative Commons Attribution (CC BY) license (https:// creativecommons.org/licenses/by/ $4.0 /)$.

\begin{abstract}
Classic and intelligent techniques aim to locate and track the maximum power point of photovoltaic (PV) systems, such as perturb and observe (P\&O), fuzzy logic (FL), artificial neural networks (ANNs), and adaptive neuro-fuzzy inference systems (ANFISs). This paper proposes and compares three intelligent algorithms for maximum power point tracking (MPPT) control, specifically fuzzy, ANN, and ANFIS. The modeling of a single-diode equivalent circuit-based $3 \mathrm{kWp}$ PV plant was developed and validated to achieve this purpose. Then, the MPPT techniques were designed and applied to control the buck-boost converter's switching device of the PV plant. All three methods use the ambient conditions as input variables: solar irradiance and ambient temperature. The proposed methodology comprises the study of the dynamic response for tracking the maximum power point and the power generated of the PV systems, and it was compared to the classic P\&O technique under varying ambient conditions. We observed that the intelligent techniques outperformed the classic $\mathrm{P} \& \mathrm{O}$ method in tracking speed, tracking accuracy, and reducing oscillation around the maximum power point (MPP). The ANN technique was the better control algorithm in energy gain, managing to recover up to $9.9 \%$ power.
\end{abstract}

Keywords: photovoltaic systems; MPPT; ANN; fuzzy; ANFIS; power recovery

\section{Introduction}

The insertion of photovoltaic (PV) systems into the world electrical matrix has grown exponentially. However, the nonlinear nature of PV arrays regarding ambient conditions and unstable climatic factors hinders the extraction of the maximum power provided by the PV modules. As a result, the PV modules can extract a false MPP and convert less solar energy into electrical energy. Consequently, there is a reduction in the efficiency of the PV system [1].

The reduction in the efficiency of PV systems becomes substantial when it comes to photovoltaic plants with a high installed capacity. Therefore, maximum power point tracking (MPPT) techniques that are minimally more efficient than others can increase the generated power significantly. As a result, researchers have studied and developed MPPT techniques extensively.

MPPT is a technique that allows PV arrays to operate at the maximum power production based on a control system. They diverge in aspects such as the number of required sensors, complexity, cost, speed convergence, and accurate tracking under irradiance and/or temperature variations [2].

MPPT techniques are helpful to add speed in the search process for the new MPP when the ambient conditions change and, consequently, the MPP of the module is modified. For example, an inefficient MPPT technique can follow the MPP under normal 
ambient conditions with little or no damage to the power supplied to the system. However, on the other hand, this same technique may not keep up with the MPP when there are many passing clouds in short time intervals or a false MPP is detected. Unfortunately, this can damage the power generation of the PV system. Therefore, choosing the ideal MPPT technique according to ambient conditions is important to extract the maximum power generation.

Artificial intelligence (AI) techniques are successful in nonlinear systems, such as photovoltaics. Therefore, the PV system in this paper will use AI techniques as MPPT control algorithms. Among the existing AI techniques, artificial neural networks (ANNs) and fuzzy logic (FL) are the most studied MPPT techniques in the literature.

Compared to classic techniques, AI techniques show better extraction of the maximum power from PV modules. After all, they work with nonlinear systems in a fast, flexible, and reliable way. Such characteristics are fundamental for situations of rapid change in ambient conditions $[3,4]$.

Moreover, the choice of the DC-DC converter is important because it needs to track the MPP regardless of the ambient conditions. In other words, it cannot have a non-operational region on its $\mathrm{I}-\mathrm{V}$ characteristic curve to ensure maximum energy is transferred to the load regardless of the environmental conditions used during the test [5].

These characteristics can be found in buck-boost converters [6], and they are essential in regions with a dry and sunny tropical climate as in the present paper. Therefore, we chose to use a buck-boost converter in this work, although this converter type is infrequent in the literature.

For instance, Aldobhani and John [7,8] developed a new MPPT technique based on an adaptive neuro-fuzzy inference system (ANFIS) and applied a buck-boost converter. The short-circuit current $\left(I_{S C}\right)$ and open-circuit voltage $\left(V_{O C}\right)$ of the PV array were the input variables. For training, the dataset had 39 samples. As a result, the authors estimated the maximum power point voltage $\left(V_{M P P}\right)$ with errors under $2 \%$. Additionally, they observed high efficiency and low fluctuation in the output.

Otiene, Nyakoe, and Wekesa [9] also designed a PV system with MPPT based on an ANFIS and applied a buck-boost converter. The researchers used irradiance $(G)$ and ambient temperature $\left(T_{A M B}\right)$ as input variables. They used seven Gaussian membership functions (MFs) for $G$ and three for $T_{A M B}$. The estimate of the $V_{M P P}$ was the output variable, and it helped control the switch duty cycle of the DC-DC converter. In addition, the authors performed a qualitative analysis.

Posteriorly, Panda, Pathak, and Srivastava [10] compared MPPT based on P\&O with MPPT based on a fuzzy controller. Both MPPT techniques were used in a PV system with a buck-boost converter [11]. The researchers analyzed the response time of two MPPT controllers. They observed that the P\&O controller took $167.6 \mathrm{~ms}$ to track the MPP, whereas the fuzzy MPPT controller took $12.2 \mathrm{~ms}$, i.e., the fuzzy MPPT controller reduced the maximum power tracking time by $88.18 \%$.

Ahmed and Salam [12] created a simulated PV system with a buck-boost converter and P\&O as an MPPT technique. The PV system was connected to a load. The simulated results showed a $\mathrm{P} \& \mathrm{O}$ algorithm with $45 \mathrm{~ms}$ of settling time and oscillations around the MPP in steady state under normal ambient conditions [13].

Ahmed and Salam [14] developed a new simulated study with the same PV system used in $[7,8]$ the following year. They analyzed the PV system under uniform, step, and abrupt (dynamic) changing ambient conditions. The researchers observed that the $\mathrm{P} \& \mathrm{O}$ algorithm exhibited an initial start-up speed between 120 and $300 \mathrm{~ms}$ and a re-tracking speed after step atmospheric change between 40 and $60 \mathrm{~ms}$.

Shiau et al. [15] studied different buck-boost converter topologies applied to a PV system using fuzzy as an MPPT control algorithm. All topologies were analyzed in Matlab/Simulink ${ }^{\circledR}$ under ambient conditions. The authors did not examine the parameters of the dynamic response. They just ensured that all buck-boost converter topologies almost perfectly reached the MPP. 
Arora and Gaur [16] compared an ANFIS and an ANN as MPPT control algorithms applied to a grid-connected PV system with a buck-boost converter. For training, the dataset had 300,001 samples collected from the incremental conductance algorithm. The input variables were the error and its associated change in error with nine MFs for each. This error expressed the derivative of the output power of the PV array concerning the output voltage and current. The output variable was the duty cycle which tunes the MPPT controller to locate the MPP.

Arora and Gaur [16] used fifteen neurons and a tangent sigmoid activation function in the hidden layer in a modeled ANN algorithm. The output layer had a linear activation function. The results showed $100 \%$ efficiency in tracking the MPP with the ANFIS algorithm, with a settling time of $0.105 \mathrm{~s}$ and oscillations of $0.115 \mathrm{~s}$. In contrast, the ANN algorithm achieved $99.83 \%$ efficiency in tracking the MPP, with a settling time of $0.125 \mathrm{~s}$ and fluctuations of $0.130 \mathrm{~s}$.

Simultaneously, Martin and Vazquez [17] conducted a comparative analysis of control methods to extract the maximum power from the PV system under changeable ambient conditions. The PV system had a buck-boost converter connected to a load. The authors conducted simulated and experimental analyses and achieved an efficiency of $96 \%$ for the $\mathrm{P} \& \mathrm{O}$ algorithm and $98.2 \%$ for the fuzzy and ANFIS control algorithms.

Belhachat and Larbes [18] created an intelligent MPPT controller based on an ANFIS that predicted and extracted the global maximum power point from the PV array under partial shading conditions. The authors used different PV array configurations and linked them to the buck-boost converter and a charge. The output variable of the projected ANFIS was the output power of each PV configuration, and the two input variables were the voltage and current. The method was trained with three Gaussian MFs in the input and nine fuzzy rules.

The authors observed fast tracking of the real MPP and negligible oscillations. Therefore, the simulation results demonstrated that the proposed technique efficiently tracks 99.92\% under partial shading conditions. In addition, the developed ANFIS proved robustness against sudden irradiance level changes during partial shading.

At the same time, Karagöz and Demirel [19] proposed a hybrid MPPT technique with a modified bat algorithm and the $\mathrm{P} \& \mathrm{O}$ algorithm. The authors used the standard bat algorithm and standard $\mathrm{P} \& \mathrm{O}$ algorithm to compare the results. All MPPT algorithms were simulated under standard test conditions and partially shaded conditions. Furthermore, the MPPT algorithms were applied in a PV system with a buck-boost controller [20]. Karagöz and Demirel [19] observed an oscillation around the MPP between 4 and $20 \mathrm{~W}$ when the P\&O algorithm was used. In addition, they calculated the MPPT P\&O efficiency between $80.26 \%$ and $99.03 \%$.

A simulation of a stand-alone PV system was developed by Khanam and Foo [21]. They conducted a comparison between MPPT with the P\&O algorithm and an ANN algorithm. The $\mathrm{P} \& \mathrm{O}$ results showed a settling time between 62.78 and $72.13 \mathrm{~ms}$. The ANN algorithm results were compared with those of the $\mathrm{P} \& \mathrm{O}$ algorithm qualitatively by the authors. They affirmed that the ANN provided more accurate and faster results than $\mathrm{P} \& \mathrm{O}$ when used as an MPPT algorithm [22].

Ahmed and Salam [23] developed and analyzed another MPPT algorithm of a PV system with a buck-boost converter. This time, they created a modified P\&O algorithm, and Riaz et al. [24] affirmed it to be an effective solution for detecting uniform and partial shading conditions. The results showed a settling time of $250 \mathrm{~ms}$ and an overall efficiency of around $99 \%$ under any atmospheric variations.

A comparative study among buck, boost, and buck-boost converters applied to a PV system connected to a load was executed by Kumar, Rathor, and Bahrani [25]. The researchers also compared fuzzy and $\mathrm{P} \& \mathrm{O}$ as MPPT control techniques. They concluded that the buck-boost converter offered a better performance. The $\mathrm{P} \& \mathrm{O}$ and fuzzy algorithms achieved $86 \%$ and $97 \%$ efficiency. 
Andrew-Cotter, Uddin, and Amin [26] designed an ANFIS algorithm to control the buck-boost converter switching of a grid-connected PV system. The input variables of the ANFIS architecture were the voltage and current of the PV array, both with two Gaussian MFs. The analyses showed that the ANFIS algorithm had a faster response and fewer oscillations than the classic perturb and observe $(\mathrm{P} \& \mathrm{O})$ technique. In addition, the authors calculated a conversion efficiency of $97 \%$ for the ANFIS under all irradiance levels.

Rajavel and Rathina [27] separately compared buck, boost, and buck-boost converters connected to a PV system with MPPT based on FL. The error and its associated change of error (with five MFs for each) were the input variables, and the duty cycle switching signal was the output variable. The authors analyzed the resulting graphics qualitatively and concluded that the buck-boost converter proved to have better efficiency and a good performance compared with the boost and buck converters.

Considering the brief discussion above, the present research proposes developing MPPT algorithms based on the ANN, FL, and ANFIS intelligent techniques to track the MPP of a $3 \mathrm{kWp}$ photovoltaic system under varying irradiance conditions and ambient temperature. The PV system is composed of a PV array, a buck-boost converter, and a charge. The MPPT intelligent algorithms separately connected to the PV system can minimize the adverse effects that climate change causes to the PV system during power generation.

The ANN, FL, and ANFIS intelligence techniques are attractive because they have strong generalization skills, good explanations through diffuse rules, and/or easy incorporation of language and numerical knowledge to solve problems. Additionally, some can provide a systematic calculation to deal with incomplete sensory information [18].

The irradiance $(G)$ and ambient temperature $\left(T_{A M B}\right)$ were the ambient parameters chosen as the input variables. This choice is justified considering that both parameters are ambient conditions that severely influence the power delivered by the PV modules.

This paper is briefly structured as follows. Section 2 describes the PV modeling developed in Matlab/Simulink ${ }^{\circledR}$. Then, Section 3 explains the designed MPPT algorithms. Section 4 presents the results of the simulations. Finally, the main conclusions are discussed in Section 5.

\section{Photovoltaic System}

The block diagram of the photovoltaic system adopted for this research is shown in Figure 1. It comprises 14 series-connected PV modules, a buck-boost DC-DC converter, an MPPT algorithm, and a load. A capacitor between the PV array and DC-DC converter reduces noises [28].

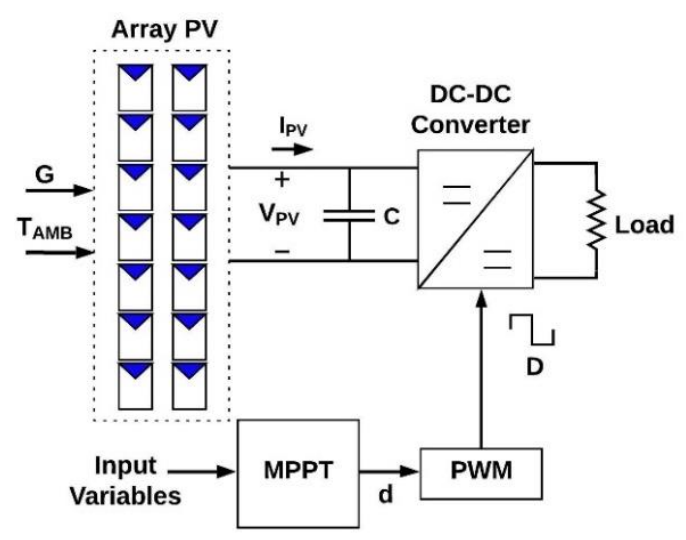

Figure 1. PV system.

Figure 2 shows the installation of the PV array used in this research. The PV system is installed at the Federal Rural University of the Semi-Arid (UFERSA), located in the city of Mossoró $\left(5^{\circ} 11^{\prime} 17^{\prime \prime} \mathrm{S}, 37^{\circ} 20^{\prime} 39^{\prime \prime} \mathrm{W}\right)$. Mossoró belongs to the Fortaleza time zone (Greenwich Mean Time (GMT) - $3 \mathrm{~h}$ ). The system is a $3 \mathrm{kWp}$ PV plant. 


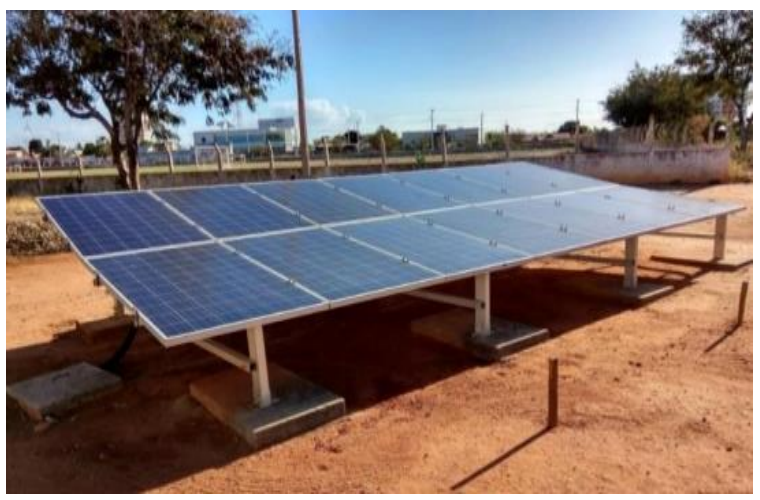

Figure 2. PV array.

The PV module modeling and buck-boost converter components are discussed in Sections 2.1 and 2.2, respectively. The MPPT algorithm developed will be explained in a separate section.

\subsection{PV Module Modeling}

The current extracted from each PV module is based on the single-diode model. The model was exhaustively discussed in [29]. The diode ideality constant $(n)$ used in the model was empirically chosen as 1 to improve the model fit.

Some authors have investigated how to estimate the ideality factor $n[30,31]$. In the context of this work, this constant was considered as $1 \leq n \leq 1.5$ [29]. Villalva, Gazoli, and Ruppert Filho [29] clarified that designers should choose $n$ to improve the model fit so that it is close to the data provided by the manufacturer.

Another essential variable of PV module modeling is defining the PV cell temperature because the diode reverse saturation current $\left(I_{0}\right)$ of the single-diode model depends on the cell temperature $\left(T_{C E L L}\right)$. There is no temperature sensor at the PV cell $\mathrm{p}-\mathrm{n}$ junction, and placing this sensor is complex. The PV cell temperature varies with the ambient temperature and irradiance [32]. Thus, as a solution, it is possible to employ Equation (1) to find the PV cell temperature.

$$
T_{C E L L}=T_{A M B}+\frac{G}{800}(N O C T-20)+273,
$$

where $T_{A M B}$ is the ambient temperature in $\left({ }^{\circ} \mathrm{C}\right)$, and $N O C T$ is the nominal operating cell temperature $\left({ }^{\circ} \mathrm{C}\right)$.

The nominal operating cell temperature (NOCT) is a parameter offered by the manufacture and represents the $\mathrm{PV}$ cell temperature measured when $T_{A M B}$ is $20^{\circ} \mathrm{C}, \mathrm{G}$ is $800 \mathrm{~W} / \mathrm{m}^{2}$, and the wind speed is $1 \mathrm{~m} / \mathrm{s}$ [32]. This parameter links the $\mathrm{PV}$ cell temperature and weather conditions $\left(T_{A M B}\right.$ and $\left.G\right)$.

The studied PV system operates with the YL245P-29b PV module model. Table 1 describes the parameters extracted from the manufacture's datasheet [33].

Table 1. Parameters of the PV module.

\begin{tabular}{cccccccc}
\hline Parameter & Value & Parameter & Value & Parameter & Value & Parameter & Value \\
\hline$V_{O C}$ & $37.5 \mathrm{~V}$ & $k_{V}$ & $-0.1248 \mathrm{~V} / \mathrm{K}$ & $N_{P}$ & 1 & $V_{M P P}$ & $29.6 \mathrm{~V}$ \\
$I_{S C}$ & $8.83 \mathrm{~A}$ & $N O C T$ & $46{ }^{\circ} \mathrm{C}$ & $P_{M P P}$ & $245 \mathrm{~W}$ & $R_{S H}$ & $404.1 \Omega$ \\
$k_{i}$ & $0.004415 \mathrm{~A} / \mathrm{K}$ & $N_{S}$ & 60 & $I_{M P P}$ & $8.26 \mathrm{~A}$ & $R_{S}$ & $0.411 \Omega$ \\
\hline
\end{tabular}

The manufacture's datasheet does not provide the $R_{S H}$ and $R_{S}$ values. Therefore, the $R_{S H}$ and $R_{S}$ model parameters were calculated (see Table 1 and Appendix A).

The methods to extract the model parameters have been extensively explored in the literature [34-36]. Nevertheless, most of them demand sensing and equipment, or even data that are not always available. Therefore, the method chosen was developed by 
Villalva, Gazoli, and Ruppert Filho [29]. It is an efficient and consolidated method and requires just the data available on the manufacturer's datasheet. The method is explained in Appendix A.

Figure 3 shows the developed model using MATLAB/Simulink ${ }^{\circledR}$ software. The green blocks are input variables, the yellow blocks are output variables, the orange blocks are PV module parameters, and the blue blocks are masks containing equations developed and discussed previously. Furthermore, a first-order filter was employed as a feedback transfer function to avoid a loop error [37]. $T_{C}$ is the filter time constant, and the $T_{C}$ value is equal to the sample time.

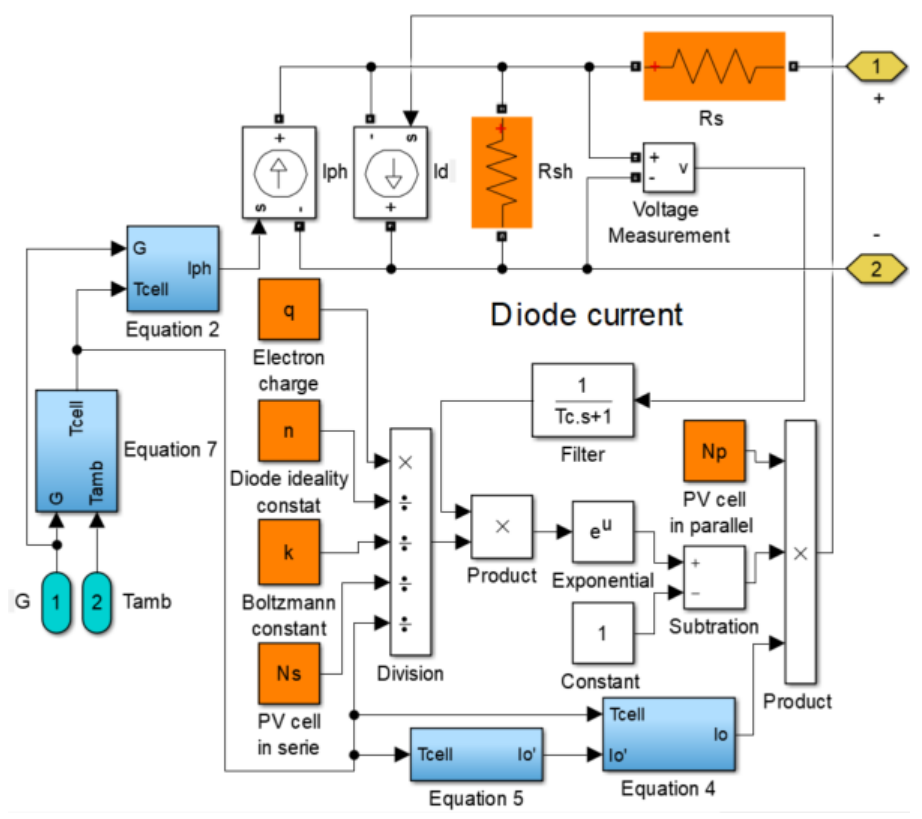

Figure 3. Modeling of the PV cell.

After defining the PV module modeling, fourteen PV modules were series connected using MATLAB/Simulink ${ }^{\circledR}$ to form the $3 \mathrm{kWp} \mathrm{PV}$ array, similar to the real PV system. Section 2.2 describes the components of the buck-boost DC-DC converter.

\subsection{Buck-Boost Converter}

A buck-boost converter is essentially composed of a switching device, a capacitor (C), and an inductor $(L)$ [18]. The MOSFET (metal-oxide-semiconductor field-effect transistor) was chosen as a switching device since it operates at a high frequency, avoiding audible noise. Additionally, a PWM (pulse width modulation) signal is responsible for turning these switches on and off. Therefore, the MPPT algorithm is responsible for controlling the PWM duty cycle $(D)$.

Figure 4 shows the scheme of the buck-boost converter modeled in MATLAB/ Simulink ${ }^{\circledR}$. The buck-boost converter and the mask representing the PV array (in blue) are connected. Moreover, an input capacitor $\left(C_{1}\right)$ is inserted to reduce oscillations. 


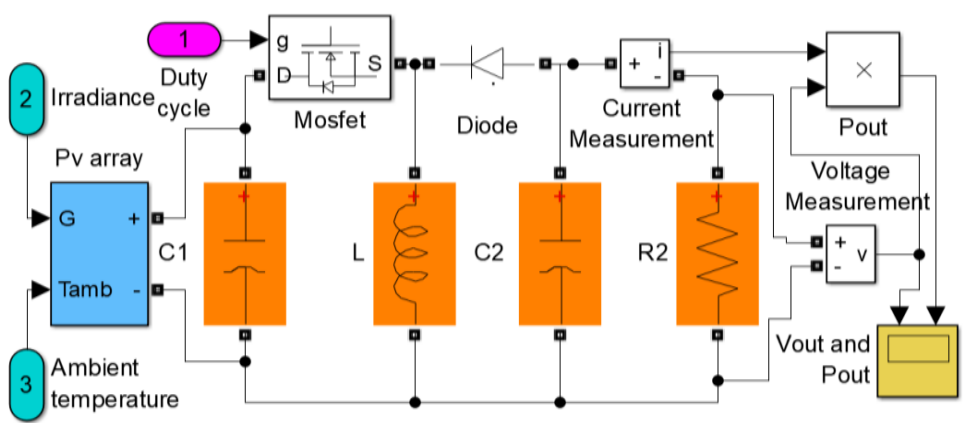

Figure 4. Buck-boost converter with PV array and input capacitor.

The components (in orange) have a recommended minimum value obtained by calculation. Table 2 shows the final values chosen. Furthermore, the output variable of the PV system is in yellow, and the PWM duty cycle is in pink.

Table 2. Parameters of the buck-boost converter by scenario.

\begin{tabular}{cccccc}
\hline Parameter & Value & Parameter & Value & Parameter & Value \\
\hline PV module & 14 & $V_{\text {OUT }}=V_{R}$ & $480 \mathrm{~V}$ & $C_{1}=C_{2}$ & $20 \mu \mathrm{F}$ \\
$P_{M P P}$ & $3430 \mathrm{~W}$ & $R$ & $67.15 \Omega$ & $f$ & $50 \mathrm{kHz}$ \\
$V_{I N}=V_{M P P}$ & $414.4 \mathrm{~V}$ & $L$ & $5.6 \mathrm{mH}$ & $\Delta I_{M A X}=\Delta V_{M A X}($ Ripple $)$ & $10 \%$ \\
\hline
\end{tabular}

After modeling the buck-boost converter and defining the load, Section 3 discusses the MPPT algorithms developed and used to control the converter.

\section{Methodology}

To develop the proposed research, it was necessary to divide the work into six stages. Figure 5 illustrates the methodological structure of the study.

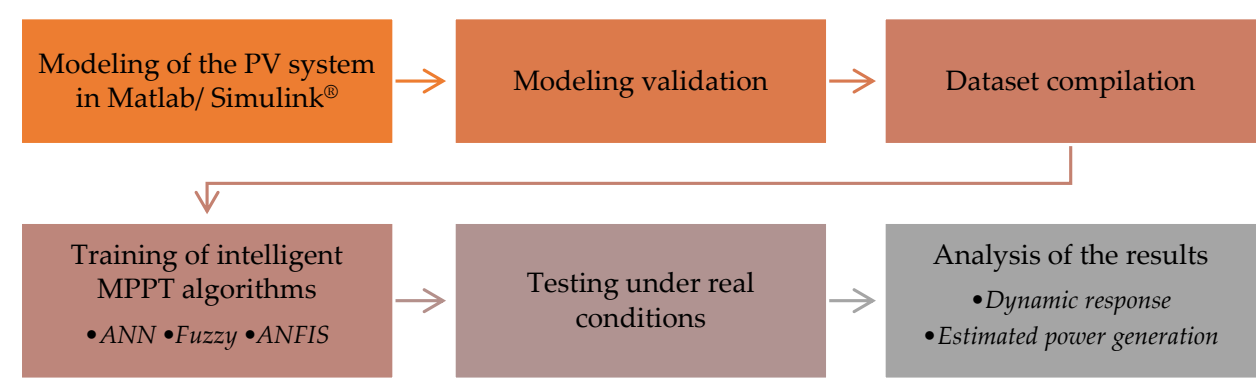

Figure 5. Stages of the methodology.

The modeling of the PV system in Matlab/Simulink ${ }^{\circledR}$ under ambient conditions is shown in Section 2. Therefore, to validate this modeling, the output power was compared in the real PV system with the $P_{M P P}$ of the modeling in MATLAB/Simulink ${ }^{\circledR}$ software. The systems with different MPPT techniques were submitted to the same ambient conditions. Afterwards, the simulation dataset was expanded to conduct the third step of the methodology (Figure 5).

The $G$ parameter varies between 100 and $1100 \mathrm{~W} / \mathrm{m}^{2}$, with a step of $100 \mathrm{~W} / \mathrm{m}^{2}$. Likewise, the $T_{A M B}$ parameter considers temperature values between 15 and $45^{\circ} \mathrm{C}$, with an increment of $5{ }^{\circ} \mathrm{C}$. In contrast, the $D$ parameter was calculated.

For each $G$ and $T_{A M B}$ value, $P_{M P P}$ was extracted. Therefore, knowing the fixed load value, the maximum power point voltage $\left(V_{M P P}\right)$ was calculated using Equation (2). $V_{M P P}$ is the output voltage of the PV system. 


$$
V_{M P P}=\sqrt{R \cdot P_{M P P}}
$$

where $R$ is the load in $(\Omega)$ (Table 2), $V_{M P P}$ is the maximum power point voltage in $(\mathrm{V})$, and $P_{M P P}$ is the maximum power point power in (W).

After, the duty cycle $(D)$ was calculated for each pair of ambient conditions $G$ and $T_{A M B}$ using Equation (3).

$$
D=\frac{\left|V_{\text {OUT }}\right|}{V_{I N}+\left|V_{\text {OUT }}\right|},
$$

where $V_{O U T}$ is $V_{M P P}$ or the buck-boost output voltage in $(\mathrm{V})$, and $V_{I N}$ is the buck-boost

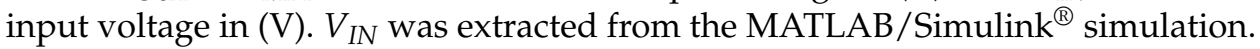

With 77 combinations of $G$ and $T_{A M B}, 77$ duty cycle values were obtained. $D$ ranged from 0.2582 to 0.6193 . Therefore, the dataset of this paper is a compilation of parameters $G, T_{A M B}$, and $D$. At the end of the compilation, a dataset with 77 samples was obtained to train AI techniques used as an MPPT algorithm in this research.

The fourth step is the modeling and training of the MPPT algorithms. Artificial intelligence techniques are used as MPPT algorithms since they can deal with the nonlinearity, complexity, and uncertainties of these systems, often through robust and low-cost solutions [2]. In this study, the ANN, fuzzy logic, and ANFIS MPPT algorithms were used in the PV system (Figure 1).

The MPPT algorithm models use the $G$ and $T_{A M B}$ as input variables. The output variable is the duty cycle $D$. Figure 6 illustrates the scheme developed in MATLAB/Simulink ${ }^{\circledR}$ for all proposed MPPT algorithms in this study.

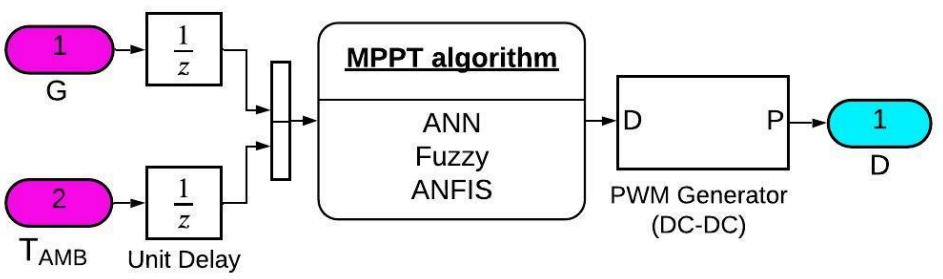

Figure 6. Scheme of MPPT with the AI algorithms.

Empirically, the switching frequency chosen for the PWM generator (Figure 6) was $50 \mathrm{kHz}$. The sampling time rate had its value established as the inverse frequency, i.e., $20 \mu \mathrm{s}$. The "Unit Delay" blocks (Figure 6) represent the signal discretization.

Finally, it is necessary to train the intelligent algorithms using a dataset with 77 samples. The training of the ANN, FL, and ANFIS algorithms is described in Section 3.1, Section 3.2, and Section 3.3, respectively.

\subsection{MPPT Algorithms Based on ANN}

Artificial neural networks (ANNs) are computational models inspired by the human brain. They are composed of a set of processing units known as artificial neurons. The synaptic weight vectors interconnect these artificial neurons [38].

In MPPT applications, the most common ANN used is the multilayer perceptron with a feed-forward architecture, usually with three layers: an input layer, a hidden layer, and an output layer. Moreover, the performance function of the network is the mean square error (MSE) [38].

The ANN was trained using the MATLAB/Simulink ${ }^{\circledR}$ software. All considered scenarios used $70 \%$ of the data points for training, $15 \%$ of the data points for validation, and $15 \%$ of the data points for testing. Table 3 shows some parameters used for training the ANN. 
Table 3. Main parameters of the ANN.

\begin{tabular}{cccc}
\hline Parameter & Data & Parameter & Data \\
\hline Network type & Multilayer Perceptron & Number of neurons & $(5,1)$ \\
Training algorithm & Levenberg-Marquardt & Activation function & (tansigmoid, pureline) \\
Inputs & {$\left[G T_{A M B}\right]$} & Number of samples in dataset & 77 \\
Outputs & {$[D]$} & Epochs & 9 \\
Number of layers & 2 & MSE & $2.4677 \times 10^{-8}$ \\
$\mathrm{R}^{2}$ & 1 & & \\
\hline
\end{tabular}

\subsection{MPPT Algorithms Based on Fuzzy Logic}

The most critical aspect of fuzzy logic (FL) is converting inaccurate and qualitative information into numerical values. When applied to PV systems as an MPPT control algorithm, FL stands out for not needing an accurate mathematical model and dealing with the nonlinearity of the PV system [39].

The MPPT training based on FL used 11 triangular membership functions (MFs) for the $G$ input variable, 7 triangular MFs for the $T_{A M B}$ input variable, and 5 triangular MFs for the $D$ output variable.

After establishing the MFs, IF/THEN statements were used to define the FL system rules. Table 4 shows the input MF settings and the fuzzy rules applied.

Table 4. Rule base matrix of a fuzzy controller.

\begin{tabular}{|c|c|c|c|c|c|c|c|}
\hline $\begin{array}{ll}\text { Input 1 } & \text { Input 2 } \\
\end{array}$ & $\begin{array}{c}15 \\
{[151520]}\end{array}$ & $\begin{array}{c}20 \\
{\left[\begin{array}{ll}15 & 20 \\
25\end{array}\right]}\end{array}$ & $\begin{array}{c}25 \\
{[202530]}\end{array}$ & $\begin{array}{c}30 \\
{\left[\begin{array}{lll}25 & 30 & 35\end{array}\right]}\end{array}$ & $\begin{array}{c}35 \\
{[303540]}\end{array}$ & $\begin{array}{c}40 \\
{[354045]}\end{array}$ & $\begin{array}{c}45 \\
{[404545]}\end{array}$ \\
\hline $\begin{array}{c}\mathbf{1 0 0} \\
{[100100 \text { 200] }}\end{array}$ & LO & LO & LO & LO & LO & LO & LO \\
\hline $\begin{array}{c}200 \\
{[100200300]}\end{array}$ & LO & ML & ML & ML & ML & ML & ML \\
\hline $\begin{array}{c}300 \\
{[200300400]}\end{array}$ & ML & ML & ML & ML & $\mathrm{M}$ & $\mathrm{M}$ & $\mathrm{M}$ \\
\hline $\begin{array}{c}400 \\
{[300400500]}\end{array}$ & M & $\mathrm{M}$ & $\mathrm{M}$ & $\mathrm{M}$ & $\mathrm{M}$ & $\mathrm{M}$ & $\mathrm{M}$ \\
\hline $\begin{array}{c}500 \\
{[400500600]}\end{array}$ & M & $\mathrm{M}$ & $\mathrm{M}$ & $\mathrm{M}$ & $\mathrm{MH}$ & $\mathrm{MH}$ & $\mathrm{MH}$ \\
\hline $\begin{array}{c}\mathbf{6 0 0} \\
{[500600700]}\end{array}$ & $\mathrm{MH}$ & $\mathrm{MH}$ & $\mathrm{MH}$ & $\mathrm{MH}$ & $\mathrm{MH}$ & $\mathrm{MH}$ & $\mathrm{MH}$ \\
\hline $\begin{array}{c}700 \\
{[600700800]}\end{array}$ & MH & $\mathrm{MH}$ & $\mathrm{MH}$ & $\mathrm{MH}$ & $\mathrm{MH}$ & $\mathrm{MH}$ & $\mathrm{MH}$ \\
\hline $\begin{array}{c}800 \\
{[700800900]}\end{array}$ & MH & MH & MH & $\mathrm{H}$ & $\mathrm{H}$ & $\mathrm{H}$ & $\mathrm{H}$ \\
\hline $\begin{array}{c}900 \\
\text { [800 } 9001000]\end{array}$ & $\mathrm{H}$ & $\mathrm{H}$ & $\mathrm{H}$ & $\mathrm{H}$ & $\mathrm{H}$ & $\mathrm{H}$ & $\mathrm{H}$ \\
\hline $\begin{array}{c}1000 \\
{[90010001100]}\end{array}$ & $\mathrm{H}$ & $\mathrm{H}$ & $\mathrm{H}$ & $\mathrm{H}$ & $\mathrm{H}$ & $\mathrm{H}$ & $\mathrm{H}$ \\
\hline $\begin{array}{c}\mathbf{1 1 0} \\
{[100011001100]}\end{array}$ & $\mathrm{H}$ & $\mathrm{H}$ & $\mathrm{H}$ & $\mathrm{H}$ & $\mathrm{H}$ & $\mathrm{H}$ & $\mathrm{H}$ \\
\hline
\end{tabular}

Overall, the Mamdani fuzzy controller employed 77 fuzzy rules. Table 5 summarizes the main characteristics that set up the modeled fuzzy controller.

\subsection{MPPT Algorithms Based on ANFIS}

Adaptive neuro-fuzzy inference systems (ANFISs) are hybrid intelligence techniques that combine ANN and FL techniques. In an ANFIS, a particular ANN architecture incorporates a fuzzy inference system (FIS). Therefore, the fuzzy controller receives a learning algorithm [40]. 
Table 5. Parameters of the fuzzy controller with the input variables $G$ and $T_{A M B}$.

\begin{tabular}{|c|c|c|c|c|c|}
\hline Parameter & Data & Parameter & Data & Parameter & Data \\
\hline Type & Mamdani & Number of rules & 77 & & 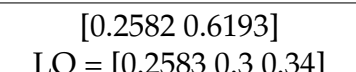 \\
\hline Inputs & {$\left[G T_{A M B}\right]$} & Type of input MF & trimf & & 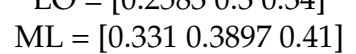 \\
\hline Output & {$[D]$} & Type of output MF & trimf & Output range & $\mathrm{M}=\left[\begin{array}{lll}0.4028 & 0.44 & 0.475\end{array}\right]$ \\
\hline Number of input MFs & [11 7] & Input range 1 & [100 1100] & & $\mathrm{MH}=\left[\begin{array}{lll}0.47 & 0.5085 & 0.547\end{array}\right]$ \\
\hline Number of output MFs & 5 & Input range 2 & [15 45] & & $\mathrm{H}=\left[\begin{array}{lll}0.54 & 0.58 & 0.6195\end{array}\right]$ \\
\hline
\end{tabular}

However, when comparing it to other conventional MPPT techniques, ANFIS as an MPPT control algorithm applied to PV systems is still recent. Thus, this study modeled the ANFIS MPPT using the MATLAB/Simulink ${ }^{\circledR}$ software.

The ANFIS was trained using all 77 samples of the dataset. In the ANFIS architecture, each input has 5 triangular MFs, totaling 25 fuzzy rules. The output is a constant MF. Figure 7 illustrates the architecture scheme.

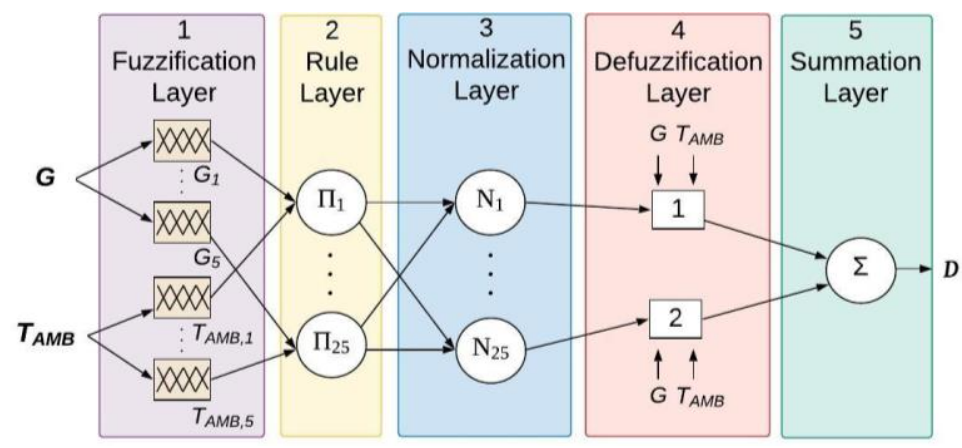

Figure 7. ANFIS architecture.

Finally, Table 6 briefly presents the main parameters of the ANFIS technique used as an MPPT control algorithm for the PV system.

Table 6. The main parameters of the ANFIS algorithm with the $G$ and $T_{A M B}$ input variables.

\begin{tabular}{cccc}
\hline Parameters & Data & Parameters & Data \\
\hline Type & Sugeno & Type of output MF & constant \\
Inputs & {$\left[G T_{A M B}\right]$} & Input range 1 & {$[1001100]$} \\
Output & {$[D]$} & Input range 2 & {$[1545]$} \\
Number of input MFs & {$[55]$} & Output range & {$[0.25820 .6193]$} \\
Number of output MFs & 25 & Training & hybrid \\
Number of rules & 25 & Iterations & 3 \\
Type of input MF & trimf & & \\
\hline
\end{tabular}

After modeling the MPPT algorithms, the PV systems were simulated considering different ambient conditions. Section 4 describes the ambient conditions used in the simulation, and it discusses the testing results.

\section{Results and Discussion}

Firstly, the PV system modeling is validated in Section 4.1. Then, ambient conditions are defined empirically (Section 4.2) to later analyze the dynamic response of the output power of the systems in Sections 4.3 and 4.4. Finally, the power generated by each PV system is calculated in Section 4.5 , and a critical analysis is carried out. 


\subsection{Validation of the Modeled PV System}

Primarily, the simulation results were compared with the values measured experimentally to validate the PV system modeling of Section 2. In this analysis, six real and random ambient conditions were chosen. The comparison was between the model simulation and the real PV system $P_{M P P}$ output powers. Table 7 shows the comparative results.

Table 7. Output power in the real PV system and the MPP of the modeled PV system.

\begin{tabular}{cccccc}
\hline \multirow{2}{*}{ Conditions } & \multicolumn{2}{c}{ Ambient Conditions } & Real System & \multicolumn{2}{c}{ Simulated System } \\
\cline { 2 - 6 } & $\boldsymbol{G}\left(\mathbf{W} / \mathbf{m}^{\mathbf{2}}\right)$ & $\boldsymbol{T}_{\boldsymbol{A M B}}\left({ }^{\circ} \mathbf{C}\right)$ & $\boldsymbol{P}_{\text {measured }}(\mathbf{W})$ & $\boldsymbol{P}_{\boldsymbol{M P P}, \text { simulation }}(\mathbf{W})$ & $\mathbf{e}_{\%}$ \\
\hline 1 & 294 & 23.86 & 919.25 & 935.2 & 1.73 \\
2 & 303 & 31.74 & 906.83 & 893.9 & 1.43 \\
3 & 548 & 24.65 & 1664.60 & 1629.0 & 2.14 \\
4 & 868 & 31.46 & 2099.38 & 2105.0 & 0.27 \\
5 & 957 & 31.41 & 2198.76 & 2223.0 & 1.10 \\
6 & 1134 & 30.17 & 2397.52 & 2438.0 & 1.69 \\
\hline
\end{tabular}

Observing Table 7, the modeled PV system presented results close to the values measured experimentally for all ambient conditions. Furthermore, the relative errors of the powers were between $0.27 \%$ and $2.14 \%$. Therefore, the modeling developed in Section 2 estimated correct parameters because the simulation returned results consistent with reality. Thus, it was appropriate to use the model for the elaboration of the dataset and subsequent simulation.

For the simulations, the ambient conditions needed to be defined, as shown in Section 4.2.

\subsection{Definition of Ambient Conditions}

The control algorithms from the PV system were connected separately considering the same ambient conditions to analyze the dynamic response of the output power. Table 8 details the randomly chosen ambient conditions.

Table 8. Ambient conditions and respective expected $P_{M P P}$.

\begin{tabular}{cccc}
\hline Condition & $\boldsymbol{G}\left(\mathbf{W} / \mathbf{m}^{\mathbf{2}}\right)$ & $\boldsymbol{T}_{\text {AMB }}\left({ }^{\circ} \mathbf{C}\right)$ & $\boldsymbol{P}_{\mathbf{M P P}}(\mathbf{W})$ \\
\hline Condition 1 & 303 & 24 & 961.5 \\
Condition 2 & 631 & 32 & 1684.0 \\
Condition 3 & 957 & 32 & 2205.0 \\
Condition 4 & 548 & 24 & 1640.0 \\
\hline
\end{tabular}

Table 8 also shows the expected $P_{M P P}$ in the output of the PV system. It is worth highlighting that the change in ambient conditions considers the cloud edge effect.

After estimating the expected power, the convergence speed, tracking accuracy, and oscillation around the MPP parameters were verified and are discussed in Sections 4.3 and 4.4. These parameters make up the dynamic response of the output signal. A comparison between the intelligent and classic $\mathrm{P} \& \mathrm{O}$ algorithms was also performed.

Afterwards, the PV systems were subjected to three ambient conditions of the city used in this paper. The city is located near the Equator $\left(5^{\circ} 11^{\prime} 17^{\prime \prime} \mathrm{S}, 37^{\circ} 20^{\prime} 39^{\prime \prime} \mathrm{W}\right)$, GMT-3. This city has a dry and sunny tropical climate. The extracted conditions were irradiance and ambient temperature, and the ambient conditions are explained in Section 4.2.1, Section 4.2.2, Section 4.2.3. 


\subsubsection{Normal Condition}

A day in normal conditions has a full sun and a clear sky. Therefore, the irradiance increases until close to $12: 00 \mathrm{~h}(\mathrm{GTM}-3)$ and exceeds $1000 \mathrm{~W} / \mathrm{m}^{2}$ in the region of this research. After midday, the irradiance declines until sunset. Conversely, the ambient temperature only increases on this type of sunny day. Figure 8 illustrates the ambient condition of the normal condition scenario.

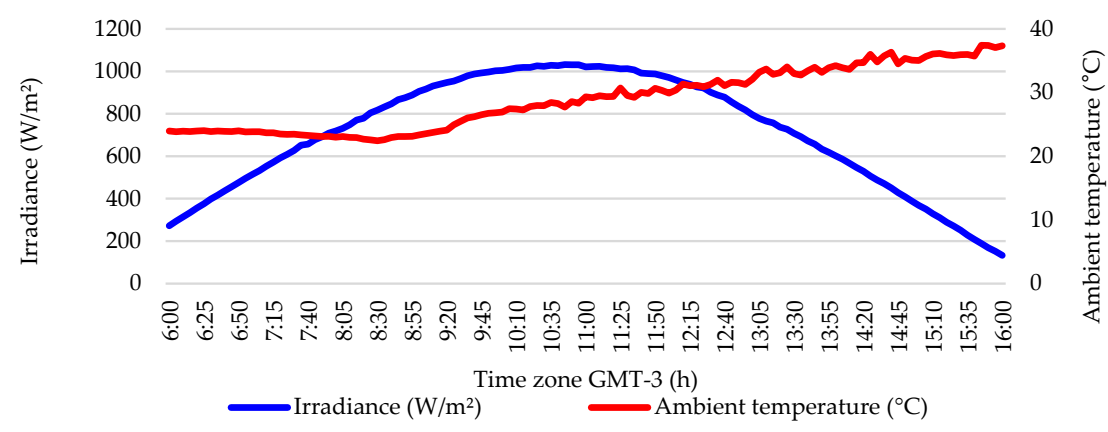

Figure 8. Normal condition.

\subsubsection{Shading Condition}

In the shading condition, it is possible to observe a behavior of the ambient temperature similar to that of the normal condition (Section 4.2.1). However, the irradiance has an actual and rapid drop near 11:00 h (GTM-3), as shown in Figure 9. This sudden change in irradiance levels is a consequence of passing clouds.

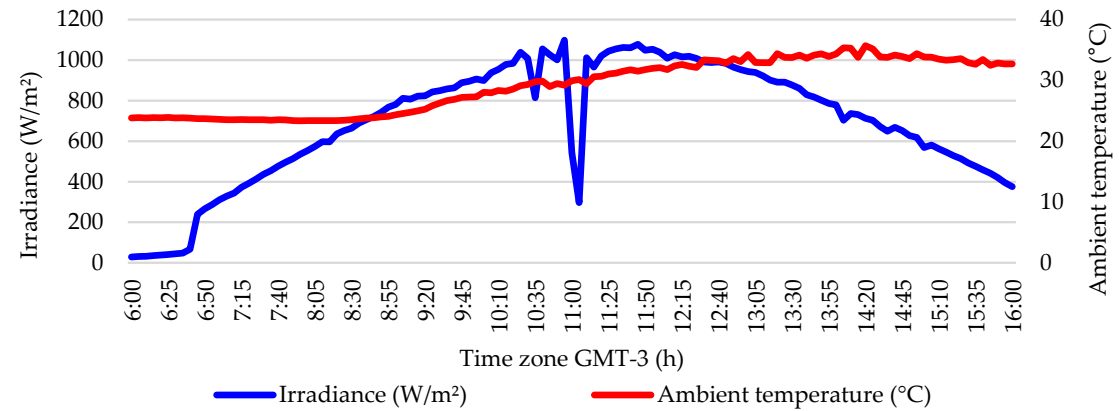

Figure 9. Shading condition.

\subsubsection{Forecasting Condition}

The forecasting condition is defined as the situation in which solar irradiance changes over time. The ambient temperature maintains the performance of only increasing throughout the day. Figure 10 shows the $G$ and $T_{A M B}$ conditions.

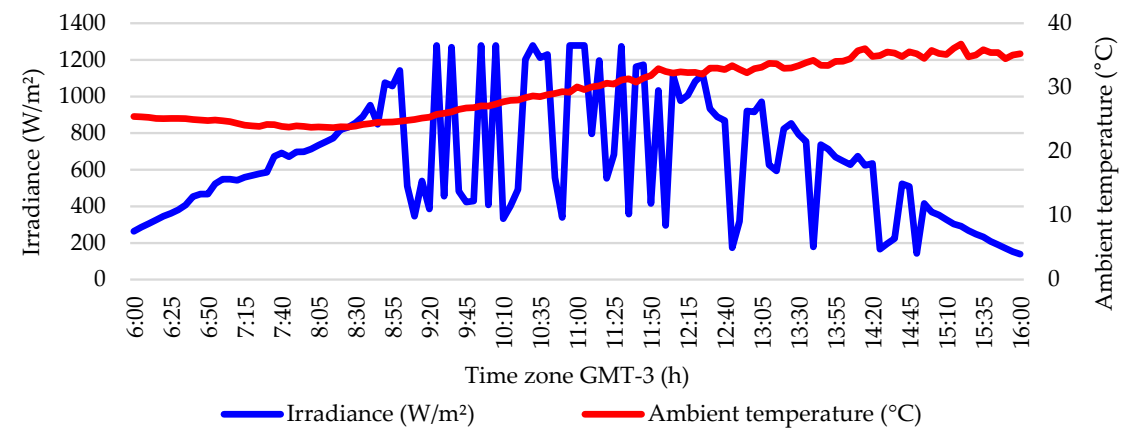

Figure 10. Forecasting condition. 
In Section 4.5, the power generated by each PV system is calculated and, finally, compared with a PV system with MPPT based on P\&O.

\subsection{Dynamic Response Analysis}

Each intelligent MPPT technique modeled and connected to the PV was submitted to the ambient conditions of Table 8. Therefore, the dynamic response of the output power was analyzed. In Figure 11, the blue curve is the expected $P_{M P P}$ value for each ambient condition.

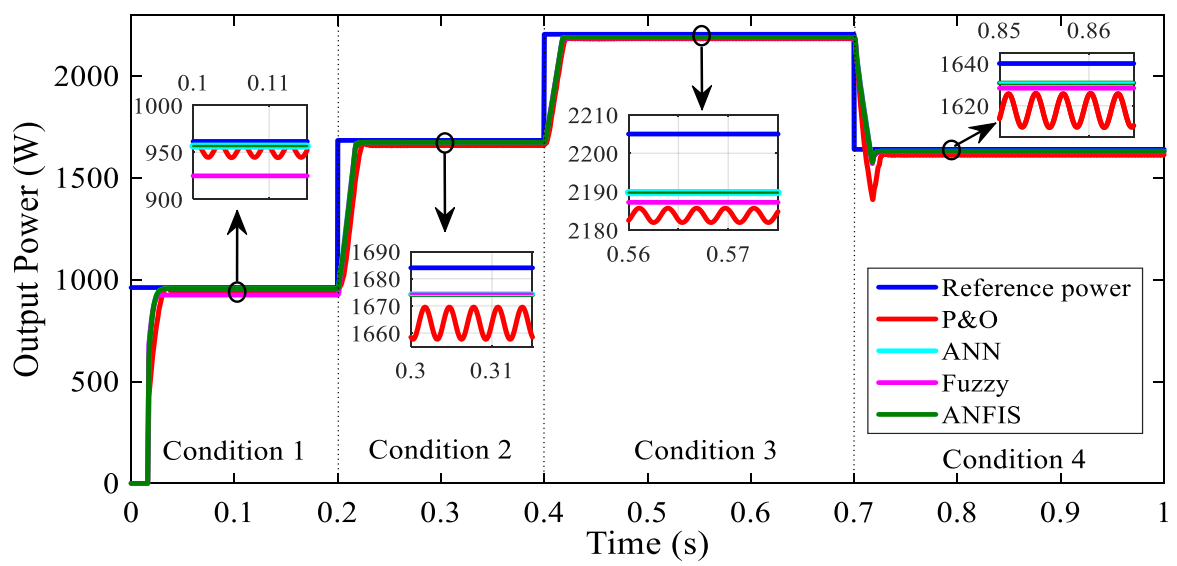

Figure 11. Comparison among output powers according to the MPPT algorithm.

Analyzing Figure 11, the ANFIS and ANN algorithms were faster in achieving the steady state. On the other hand, the P\&O algorithm was the slowest technique. Additionally, the $\mathrm{P} \& \mathrm{O}$ algorithm presented more significant oscillations around the MPP in the steady state when compared to the intelligent algorithm used as an MPPT control technique.

The convergence speed is the time that the PV system takes to achieve the steady state. Therefore, the settling time $(t s)$ was the chosen parameter. The oscillation around the MPP $(\Delta P)$ is the peak-to-peak value of the signal in the steady state. Finally, $\Delta P$ is the ratio between the peak value and the average value of the output power measured in the steady state.

Table 9 describes the settling time $(t s)$ and the oscillation around the MPP $(\Delta P)$ parameters.

Table 9. The settling time and the oscillation around the MPP parameters.

\begin{tabular}{ccccccccc}
\hline \multirow{2}{*}{ Condition } & \multicolumn{9}{c}{ ts $(\mathbf{m s})$} & \multicolumn{4}{c}{$\boldsymbol{\Delta P}(\%)$} \\
\cline { 2 - 9 } & P\&O & ANN & FUZZY & ANFIS & P\&O & ANN & FUZZY & ANFIS \\
\hline 1 & 29.16 & 23.44 & 22.24 & 23.54 & 0.57325 & 0.00020 & 0.00012 & 0.00016 \\
2 & 19.90 & 15.60 & 15.70 & 15.8 & 0.33984 & 0.00031 & 0.00012 & 0.00028 \\
3 & 15.70 & 14.10 & 14.10 & 14.3 & 0.00872 & 0.00023 & 0.00012 & 0.00026 \\
4 & 22.50 & 13.40 & 13.20 & 13.0 & 0.22308 & 0.00011 & 0.00013 & 0.00013 \\
\hline
\end{tabular}

The settling time of the $\mathrm{P} \& \mathrm{O}$ algorithm (Table 9) was longer than that of all simulated intelligent techniques, as observed in Figure 11. Overall, the ANFIS, ANN, and fuzzy algorithms showed similar settling times. Intelligent algorithms were at least $1 \mathrm{~ms}$ faster than the classic $\mathrm{P} \& \mathrm{O}$ algorithm. The lowest difference among settling times of the algorithms occurred in Condition 3.

The oscillation around the MPP $(\Delta P)$ of the intelligent techniques (ANN, fuzzy, and ANFIS) is almost undetectable because they correspond to a variation of less than $0.001 \%$. In contrast, the $\mathrm{P} \& \mathrm{O}$ shows oscillations around the MPP between $0.008 \%$ and $0.57 \%$. Therefore, expanding on the graph of Figure 11, fluctuations of the P\&O algorithm are 
observed, while the intelligent algorithms' signals do not seem to exhibit oscillation in the steady state.

Moreover, the parameter used to verify the tracking accuracy is the relative percentage error. This error compares the average power value of the PV system in the steady state with the expected $P_{M P P}$ established in Table 8.

Table 10 and Figure 12 show the results obtained with MPPT based on each AI technique. The results were also compared to the classic $\mathrm{P} \& \mathrm{O}$ technique.

Table 10. The average power of the PV system in the steady state, and the respective relative percentage error.

\begin{tabular}{cccccccccc}
\hline \multirow{2}{*}{ Condition } & \multirow{2}{*}{$\boldsymbol{P}_{\mathbf{M P P}}(\mathbf{W})$} & \multicolumn{2}{c}{ P\&O } & \multicolumn{2}{c}{ ANN } & \multicolumn{2}{c}{ FUZZY } & \multicolumn{2}{c}{ ANFIS } \\
\cline { 3 - 9 } & & $\mathbf{P}_{\mathbf{P \& O}}(\mathbf{W})$ & $\mathbf{e}_{\%}$ & $\mathbf{P}_{\text {ANN }}(\mathbf{W})$ & $\mathbf{e}_{\%}$ & $\mathbf{P}_{\text {FUZZY }}(\mathbf{W})$ & $\mathbf{e}_{\%}$ & $\mathbf{P}_{\text {ANFIS }}(\mathbf{W})$ & $\mathbf{e}_{\%}$ \\
\hline 1 & 961.5 & 951.6 & 1.03 & 956.5 & 0.52 & 924.9 & 3.81 & 956.6 & 0.51 \\
2 & 1684.0 & 1664.0 & 1.19 & 1674.0 & 0.59 & 1674.0 & 0.59 & 1674.0 & 0.59 \\
3 & 2205.0 & 2184.0 & 0.95 & 2190.0 & 0.68 & 2187.0 & 0.82 & 2190.0 & 0.68 \\
4 & 1640.0 & 1618.0 & 1.34 & 1631.0 & 0.55 & 1628.0 & 0.73 & 1631.0 & 0.55 \\
\hline
\end{tabular}

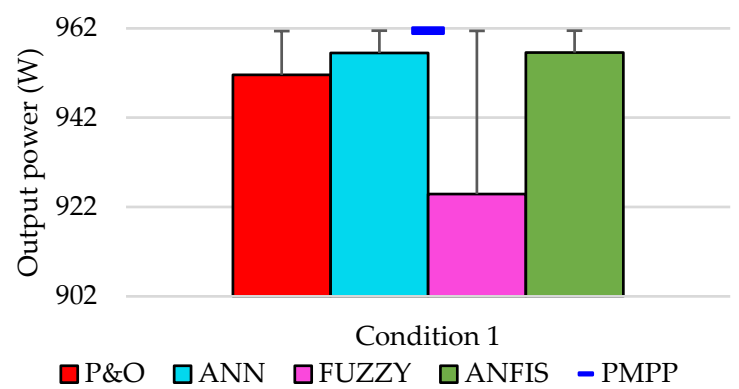

(a)

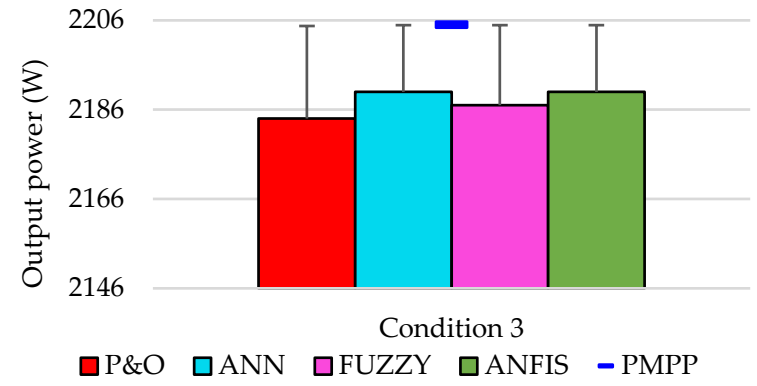

(c)

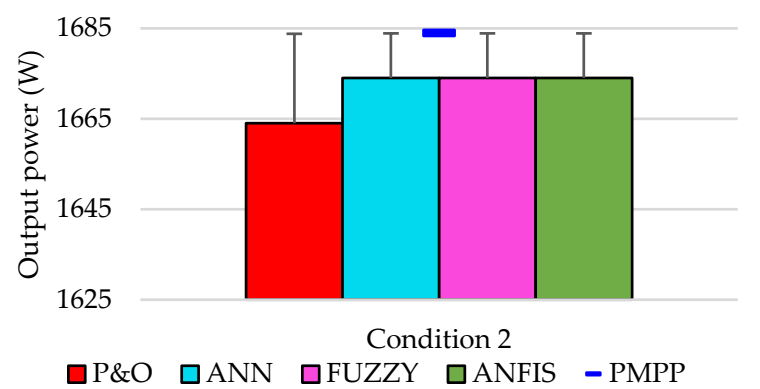

(b)

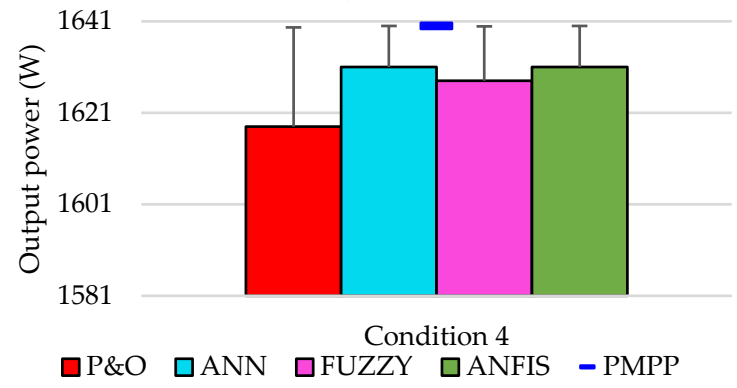

(d)

Figure 12. The average power of the PV system in the steady state and their respective error bars for (a) Condition 1 , (b) Condition 2, (c) Condition 3, and (d) Condition 4.

Table 10 and Figure 12 show that MPPT based on intelligent algorithms showed a better tracking accuracy than that with the classic $\mathrm{P} \& \mathrm{O}$ algorithm. Furthermore, the ANFIS and ANN algorithms showed better precision or a reduced relative percentage error.

Additionally, under low irradiance (Condition 1-Figure 12a), the relative percentage error of the FL algorithm (3.81\%) was higher than that of the P\&O algorithm (1.03\%). Therefore, the FL algorithm needs a fine adjustment and, consequently, more knowledge of the expert operators.

This research observed that the ANN and ANFIS algorithms perform better than the $\mathrm{P} \& \mathrm{O}$ and FL algorithms when the dynamic response is analyzed. Additionally, it was observed that the ANN and ANFIS algorithms did not need to carry out several tests to find the optimal structure during the training phase.

In contrast, while MATLAB/Simulink ${ }^{\circledR}$ software defines the ANFIS MFs, the expert operator must establish the fuzzy MFs. Therefore, reducing the number and changing the 
type of ANFIS MFs was faster and easier than those for the fuzzy MFs. Consequently, the ANFIS algorithm needs less computational effort to control the MPPT of the PV system.

Analyzing the simplicity of implementation, the ANN and fuzzy algorithms have a medium complexity. On the other hand, the ANFIS algorithm has a high complexity and requires features such as high-performance controllers. Therefore, while the ANFIS and ANN algorithms have a similar dynamic response, the ANN algorithm is better as it is more robust.

\subsection{Comparative Study}

Few studies using buck-boost as an MPPT converter were found in the literature. Anyway, Table 11 evaluates and performs a reasonable comparison of the proposed research results with previously published studies.

Table 11. Comparison with other published studies.

\begin{tabular}{|c|c|c|c|c|c|}
\hline Reference & Algorithm & $\begin{array}{l}\text { Settling Time } \\
\text { (ms) }\end{array}$ & Accuracy (\%) & $\begin{array}{l}\text { Experimentally } \\
\text { Tested }\end{array}$ & Dataset \\
\hline \multirow{3}{*}{ Proposed research } & ANN & $13.40-23.44$ & $99.32-99.48$ & \multirow{3}{*}{ No } & \multirow{3}{*}{77} \\
\hline & Fuzzy & $13.20-22.24$ & 96.19-99.41 & & \\
\hline & ANFIS & $13.00-23.54$ & $99.32-99.49$ & & \\
\hline Aldobhani and John $[7,8]$ & ANFIS & - & $98-99$ & No & 39 \\
\hline Panda, Pathak, and Srivastava [10] & Fuzzy & 12.20 & - & No & - \\
\hline \multirow{2}{*}{ Arora and Gaur [16] } & ANN & 125.00 & 99.83 & \multirow{2}{*}{ No } & \multirow{2}{*}{300,001} \\
\hline & ANFIS & 105.00 & 100 & & \\
\hline \multirow{2}{*}{ Martin and Vazquez [17] } & Fuzzy & - & 98.2 & \multirow{2}{*}{ Yes } & \multirow{2}{*}{-} \\
\hline & ANFIS & - & 98.2 & & \\
\hline Belhachat and Larbes [18] & ANFIS & - & 99.92 & No & - \\
\hline Andrew-Cotter, Uddin, and Amin [26] & ANFIS & - & 97 & No & - \\
\hline
\end{tabular}

Table 11 describes the type of algorithm, the settling time, and the method's accuracy. All missing data in papers are hyphenated in Table 11.

Among the research that used buck-boost as an MPPT converter, only two works measured the settling time. The Panda, Pathak, and Srivastava [10] study achieved a settling time close to the method proposed in the present paper. The time value is even shorter due to the smaller variations in the ambient conditions that the Panda, Pathak, and Srivastava [10] PV system was subjected to.

In contrast, the settling time of the Arora and Gaur [16] system was considerably longer than that of the proposed research. The difference can be explained because the Arora and Gaur [16] system had been connected to the grid and subjected to a slow, graded range of changing solar irradiation levels.

With respect to the accuracy, the results show that the intelligent algorithms have the best accuracy in following the MPP of the PV module compared to the P\&O algorithm. As discussed in Sections 1 and 3, this result was expected because AI techniques work better with nonlinear systems than classic techniques [3,4].

In the proposed fuzzy research, the lowest accuracy was detected among intelligent algorithms. This means the MFs and fuzzy rules directed to low irradiances need to be adjusted.

The results also show that the performance of the MPPT algorithm depends more on the quality than the quantity of the training data [41]. Specifically, assessing the Arora and Gaur [16] results, they calculated the accuracy based on the maximum power output of the PV module. The other papers of Table 11 were evaluated based on the MPP of the P-V characteristic curve. 
The present paper proposes evaluating the replacement of the classic P\&O algorithm with an intelligent algorithm. Therefore, after analyzing the dynamic response advantages of intelligent algorithms, it is known that the dynamic response influences the generated PV system power. Therefore, estimating the power generation of the PV system is as crucial as analyzing the dynamic response.

In the literature, no research was found that performed a comparative analysis of the generated power. Thus, Section 4.5 evaluates the power generation of the PV system with intelligent and classic MPPT techniques.

\subsection{Estimated Power Generation}

The estimated power generation used three ambient conditions for the PV system, called the normal condition (Figure 8), shading condition (Figure 9), and forecasting condition (Figure 10). In addition, ten hours of full sun on both days, i.e., from 6:00 a.m. to 4:00 p.m., was considered. Figure 13 shows the result of estimating the power generation of the PV system considering the different control algorithms.

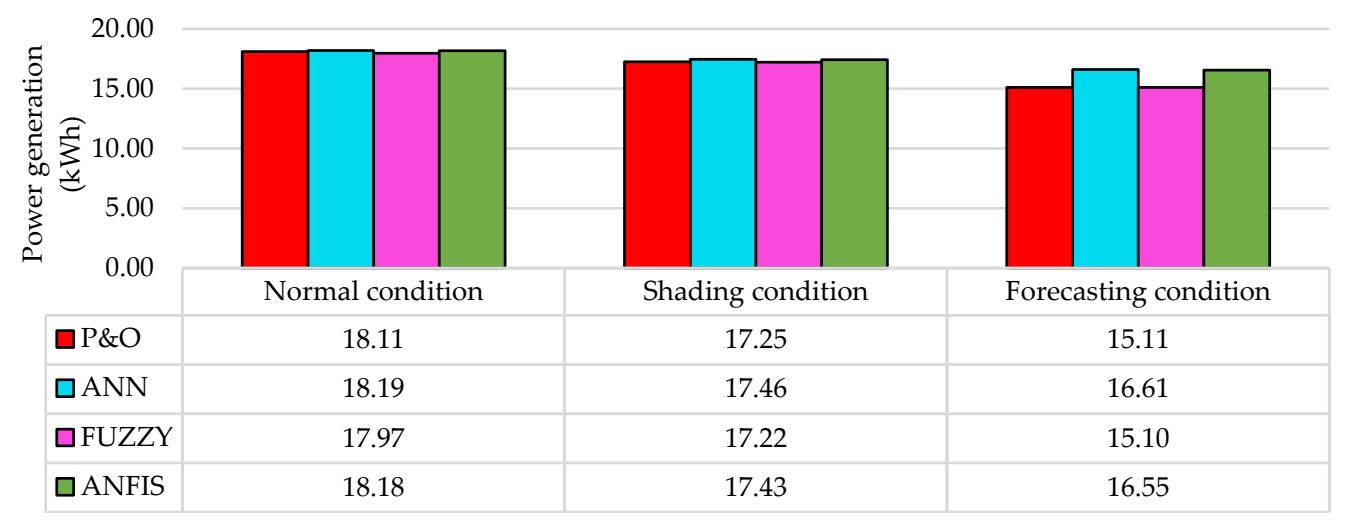

Figure 13. Power generation of the PV system for control algorithms.

The power generation of the PV system with the P\&O algorithm (Figure 13) was considered as the reference of the energy produced, i.e., it corresponds to $100 \%$ of the power generation in the experimental PV system. Therefore, replacing the $\mathrm{P} \& \mathrm{O}$ algorithm with the ANN algorithm allows recovery of $0.46 \%$ of the power generation in the normal condition. If replaced by the ANFIS algorithm, the energy recovery is $0.40 \%$. However, if the control algorithm of MPPT is fuzzy, there is an energy loss of $0.75 \%$.

In the shading condition, there is a rapidly changing irradiance near noon. Consequently, the good dynamic response of the intelligent algorithm helps to improve the recovery of the power generated.

Observing Figure 13, the exchange of the P\&O algorithm for the ANN algorithm recovers the power generated by the PV system. To be precise, the power generation of the PV system with ANN is $1.21 \%$ greater than with $\mathrm{P} \& \mathrm{O}$. The energy recovery is $1.02 \%$ when the $\mathrm{P} \& \mathrm{O}$ algorithm is replaced with the ANFIS algorithm.

Otherwise, when the $\mathrm{P} \& \mathrm{O}$ algorithm is substituted for the fuzzy algorithm, there is a loss of power generation by $0.19 \%$. In other words, the PV system with MPPT based on FL generated less power than that based on P\&O. Specifically, the fall in the power generation was from 17.25 to $17.22 \mathrm{kWh}$. A similar performance of the fuzzy algorithm was observed in the forecasting condition. MPPT based on FL showed a reduction from 15.11 to $15.10 \mathrm{kWh}$, i.e., it fell $0.04 \%$.

Additionally, in the forecasting condition, the power generation recovery was more expressive. When the $\mathrm{P} \& \mathrm{O}$ algorithm was changed for the ANN algorithm, the performance was better because the power generation increased from 15.11 to $16.61 \mathrm{kWh}$, i.e., 9.9\%. 
The ANFIS algorithm's performance was as good as the ANN algorithm's performance. The power generation rose $9.53 \%$, which means that the power generation grew from 15.11 (with P\&O) to $16.55 \mathrm{kWh}$.

Thus, these analyses allow concluding that intelligent MPPT techniques could track the MPP with an excellent dynamic response. Furthermore, the PV system with MPPT based on the ANN algorithm was remarkably useful in tracking the maximum power point in the PV system. MPPT based on ANN can recover lost energy generated with MPPT based on $\mathrm{P} \& \mathrm{O}$.

Finally, Section 5 discusses the overall conclusion of this research.

\section{Conclusions}

Using buck-boost converters as an MPPT component of PV systems is uncommon, but they are important for regions with a dry and sunny tropical climate. In this research, intelligent algorithms were applied to control MPPT, and ambient conditions ( $G$ and $T_{A M B}$ ) were considered as input variables. No similar discussion in the scientific literature has been found.

The simulations demonstrated the potential effectiveness of the PV system with MPPT based on intelligent techniques, and the following conclusions can be drawn:

- The proposed ANN and ANFIS MPPT techniques are considered an improvement of the classic $\mathrm{P} \& \mathrm{O}$ technique. If considering large-scale PV plants, they cause a subsequent increase in power generation.

- For all considered environmental conditions, the PV system with MPPT based on intelligent techniques achieved values close to the expected $P_{M P P}$. Therefore, these techniques were able to track the MPP with great accuracy.

- A high tracking speed was also observed because the intelligent algorithm localized the true $P_{M P P}$ quickly in every irradiance change.

- Intelligent techniques showed negligible oscillations around the average power value in the steady state, when compared to the classic $\mathrm{P} \& \mathrm{O}$ technique. The amplitude of the oscillation is reflected in the system stability.

- The fuzzy intelligent technique showed less satisfactory results than the ANN and ANFIS techniques. However, more knowledge of the expert operators and a fine adjustment in the fuzzy controller parameters can improve the output power of the PV system with MPPT based on FL.

- Submitting the modeled PV system to ambient conditions of regions close to the Equator line, a more significant power generation was observed when using the ANN and ANFIS intelligent algorithms in the MPPT of the PV system. The power recovery was between $0.40 \%$ and $9.9 \%$.

- The power recovery of the PV system with MPPT based on the ANN or ANFIS algorithm exceeded $1 \%$ when the ambient condition had a rapidly falling irradiance near noon in the shading condition. Furthermore, the power recovery achieved $9.9 \%$ in the forecasting condition (when the solar irradiance changes over time). The better dynamic response of these intelligent algorithms than that of the fuzzy and $\mathrm{P} \& \mathrm{O}$ algorithms justifies this recovery of power generation.

- Among the intelligent techniques simulated in the present paper, the ANN and ANFIS algorithms had a similar response. However, the ANN technique proposed a higher power generation. Moreover, the ANN algorithm has a less complex implementation, and it is more robust to noise.

- Using environmental parameters $G$ and $T_{A M B}$ as input variables has the advantage of being able to track the MPP regardless of the geographic location of the PV system. Moreover, the global maximum power point is followed with high reliability. However, its cost of implementation and applicability remain a challenge due to the increased cost of implanting the sensors. 
Author Contributions: Conceptualization, M.I.S.G. and F.M.U.d.A.; methodology, M.I.S.G.; software, M.I.S.G. and R.G.V.; validation, M.I.S.G.; formal analysis, M.I.S.G., M.D., and R.G.V.; investigation, M.I.S.G.; resources, F.M.U.d.A.; data curation, M.I.S.G. and R.G.V.; writing-original draft preparation, M.I.S.G.; writing—review and editing, M.D. and R.G.V.; visualization, F.M.U.d.A.; supervision, F.U.M.d.A. and M.D.; project administration, F.M.U.d.A. All authors have read and agreed to the published version of the manuscript.

Funding: This research received no external funding.

Institutional Review Board Statement: Not applicable.

Informed Consent Statement: Not applicable.

Conflicts of Interest: The authors declare no conflict of interest.

\section{Appendix A}

The PV module modeling was developed based on the one-diode model considering its simplicity. Therefore, Equation (A1) represents a PV module based on the one-diode model with several series- and parallel-connected PV cells [42,43].

$$
I_{P V}=N_{P} I_{P H}-N_{P} I_{0}\left[\exp \left(\frac{q\left(V_{P V}+R_{S} I_{P V}\right)}{N_{S} n k T_{C E L L}}\right)-1\right]-\frac{V_{P V}+R_{S} I_{P V}}{R_{S H}},
$$

where $I_{P V}$ represents the output current in (A); $V_{P V}$ expresses the output voltage in (V); $N_{P}$ and $N_{S}$ are the number of parallel-connected and series-connected cells, respectively; $I_{P H}$ comprises the light-generated current in (A); $I_{0}$ represents a diode saturation current in (A); and $R_{S H}$ and $R_{S}$ are the equivalent resistance in $(\Omega)$. The electron charge is $q$, and its value is a constant of $1.6 \times 10^{-19} \mathrm{C}$. Similarly, the Boltzmann constant $(k)$ is a constant value of $1.38 \times 10^{-23} \mathrm{~J} / \mathrm{K}$. Additionally, the diode ideality constant is represented for $n$.

The light-generated current $\left(I_{P H}\right)$ of a PV cell depends on the irradiance and the cell operating temperature expressed by Equation (A2).

$$
I_{P H}=\left[\left(\frac{R_{S H}+R_{S}}{R_{S H}} I_{S C}\right)+k_{i}\left(T_{C E L L}-T_{S T C}\right)\right] \frac{G}{G_{S T C}},
$$

where $I_{S C}$ represents the short-circuit current in (A); $k_{i}$ is the temperature coefficient for $I_{S C}$ in (A/K); $G$ is the irradiance; $G_{S T C}$ corresponds to the irradiance for STC (i.e., $1000 \mathrm{~W} / \mathrm{m}^{2}$ ); and $T_{\text {STC }}$ relates to the cell temperature for STC (i.e., $298 \mathrm{~K}$ ).

The diode saturation current $\left(I_{0}\right)$ is related to the cell operating temperature and is expressed by Equation (A3).

$$
I_{0}=\frac{I_{S C}+k_{i}\left(T_{C E L L}-T_{S T C}\right)}{\exp \left\{\frac{q\left[V_{o c}+k_{v}\left(T_{C E L L}-T_{S T C}\right)\right]}{n k T_{S T C}}\right\}-1}\left(\frac{T_{S T C}}{T_{C E L L}}\right)^{3} \exp \left[\frac{q E_{g 0}}{n k}\left(\frac{1}{T_{S T C}}-\frac{1}{T_{C E L L}}\right)\right],
$$

where $V_{O C}$ is the open-circuit voltage in $(\mathrm{V}) ; k_{V}$ is the temperature coefficient for $V_{O C}$ in $(\mathrm{V} / \mathrm{K})$; and $E_{g 0}$ is the bandgap energy for semiconductors and is $1.2 \mathrm{eV}$ for polycrystalline silicon at $25^{\circ} \mathrm{C}$ [29].

From Equation (A1), Equation (A4) was deduced. Then, the model resistance $R_{S H}$ and $R_{S}$ values were calculated using the Newton-Raphson iterative method and Equation (A4) for a PV module with no parallel-connected cells.

$$
R_{S H}=\frac{V_{M P P}\left(V_{M P P}+I_{M P P} R_{S}\right)}{V_{M P P} I_{P H}-V_{M P P} I_{0} e^{\left[\frac{q\left(V_{M P P}+I_{M P P} R_{s}\right)}{N_{s} n k T C E L L}\right]}+V_{M P P} I_{0}-P_{M P P}},
$$

where $V_{M P P}, I_{M P P}$, and $P_{M P P}$ correspond, respectively, to the voltage, current, and power of the maximum power point. 
Therefore, observing Equations (A1), (A2), and (A4), it is possible to assume that the shunt resistance $R_{S H}$ varies with the irradiance and ambient temperature, also depending on the series resistance $R_{S}$.

However, the model resistance $R_{S H}$ and $R_{S}$ values are unknown. Therefore, Villalva, Gazoli, and Ruppert Filho [29] recommend that $R_{S}$ must be zero when starting the iterative method, and the initial value of $R_{S H}$ is given by Equation (A5).

$$
R_{S H, \text { min }}=\frac{V_{M P P}}{I_{S C}-I_{M P P}}-\frac{V_{O C}-V_{M P P}}{I_{M P P}},
$$

where $V_{O C}$ is the open-circuit voltage in $(\mathrm{V})$. The shunt resistance minimum value $\left(R_{S H, \min }\right)$ represents the slope of the line segment between the short-circuit current $\left(I_{S C}\right)$ and the MPP operating point $\left(V_{M P P}, I_{M P P}\right)[2]$.

Villalva, Gazoli, and Ruppert Filho [29] also explained that the first model resistance $R_{S H}$ and $R_{S}$ values are initial estimates. Therefore, the true value should be found using the iterative algorithm illustrated in Figure A1.

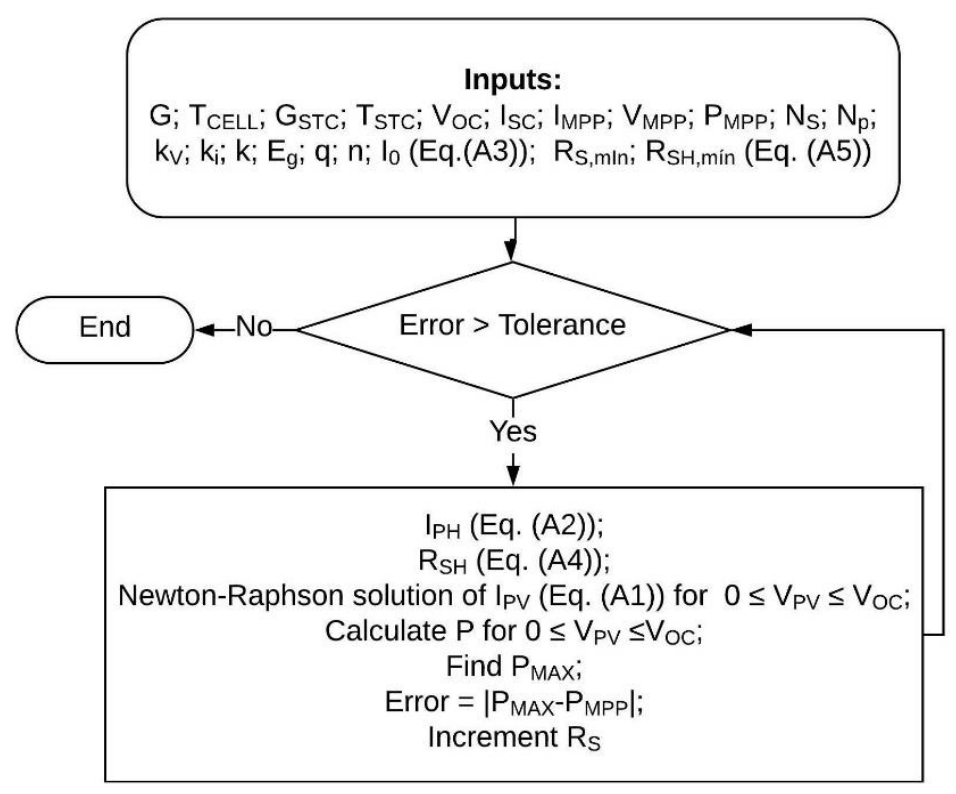

Figure A1. Flowchart with the algorithm to find $R_{S}$ and $R_{S H}$.

In Figure A1, the algorithm stops the iteration when the difference between the maximum calculated power $\left(P_{M A X}\right)$ and the maximum power from the manufacturer's data sheet $\left(P_{M P P}\right)$ is zero or less than the tolerance.

\section{References}

1. Hanzaei, S.H.; Gorji, S.A.; Ektesabi, M. A Scheme-Based Review of MPPT Techniques With Respect to Input Variables Including Solar Irradiance and PV Arrays' Temperature. IEEE Access 2020, 8, 182229-182239. [CrossRef]

2. Sumathi, S.; Ashok Kumar, L.; Surekha, P. Solar PV and Wind Energy Conversion Systems; Springer: Cham, Switerland, 2015; ISBN 978-3-319-14940-0.

3. Youssef, A.; El-Telbany, M.; Zekry, A. The role of artificial intelligence in photo-voltaic systems design and control: A review. Renew. Sustain. Energy Rev. 2017, 78, 72-79. [CrossRef]

4. Vieira, G.; de Araújo, F.M.U.; Dhimish, M.; Guerra, M.I.S. A Comprehensive Review on Bypass Diode Application on Photovoltaic Modules. Energies 2020, 13, 2472. [CrossRef]

5. Enrique, J.M.; Durán, E.; Sidrach-de-Cardona, M.; Andújar, J.M. Theoretical assessment of the maximum power point tracking efficiency of photovoltaic facilities with different converter topologies. Sol. Energy 2007, 81, 31-38. [CrossRef]

6. Reshma Gopi, R.; Sreejith, S. Converter topologies in photovoltaic applications-A review. Renew. Sustain. Energy Rev. 2018, 94, 1-14. [CrossRef]

7. Aldobhani, A.M.S.; John, R. Maximum Power Point tracking under Different Environment Conditions for Solar Photovoltaic Panels Using ANFIS Model. J. Sci. Technol. 2007, 12, 31-47. 
8. Aldobhani, A.M.S.; John, R. Maximum Power Point Tracking of PV System Using ANFIS Prediction and Fuzzy Logic Tracking. Lect. Notes Eng. Comput. Sci. 2008, 2169, 1359-1366.

9. Otieno, C.A.; Nyakoe, G.N.; Wekesa, C.W. A neural fuzzy based maximum power point tracker for a photovoltaic system. In Proceedings of the IEEE AFRICON Conference, Nairobi, Kenya, 23-25 September 2009; IEEE: Nairobi, Kenya, 2009; pp. 1-6.

10. Panda, A.; Pathak, M.K.; Srivastava, S.P. Fuzzy Intelligent Controller for the Maximum Power Point Tracking of a Photovoltaic Module at Varying Atmospheric Conditions. J. Energy Technol. Policy 2011, 1, 6-9.

11. Nabipour, M.; Razaz, M.; Seifossadat, S.G.; Mortazavi, S.S. A new MPPT scheme based on a novel fuzzy approach. Renew. Sustain. Energy Rev. 2017, 74, 1147-1169. [CrossRef]

12. Ahmed, J.; Salam, Z. A soft computing MPPT for PV system based on Cuckoo Search algorithm. In Proceedings of the 4th International Conference on Power Engineering, Energy and Electrical Drives, Istanbul, Turkey, 13-17 May 2013 ; pp. 558-562. Available online: https:/ /ieeexplore.ieee.org/document/6635669 (accessed on 5 August 2021). [CrossRef]

13. Bollipo, R.B.; Mikkili, S.; Bonthagorla, P.K. Critical Review on PV MPPT Techniques: Classical, Intelligent and Optimisation. IET Renew. Power Gener. 2020, 14, 1433-1452. [CrossRef]

14. Ahmed, J.; Salam, Z. A Maximum Power Point Tracking (MPPT) for PV system using Cuckoo Search with partial shading capability. Appl. Energy 2014, 119, 118-130. [CrossRef]

15. Shiau, J.K.; Lee, M.Y.; Wei, Y.C.; Chen, B.C. Circuit Simulation for Solar Power Maximum Power Point Tracking with Different Buck-Boost Converter Topologies. Energies 2014, 7, 5027-5046. [CrossRef]

16. Arora, A.; Gaur, P. Comparison of $\mathrm{f}$ ANN and ANFIS based MPPT controller for grid connected PV Systems. In Proceedings of the IEEE Indicon 2015, New Delhi, India, 17-20 December 2015; pp. 1-6.

17. Martin, A.D.; Vazquez, J.R. MPPT algorithms comparison in PV systems: P\&O, PI, neuro-fuzzy and backstepping controls. Proc. IEEE Int. Conf. Ind. Technol. 2015, 2015, 2841-2847. [CrossRef]

18. Belhachat, F.; Larbes, C. Global maximum power point tracking based on ANFIS approach for PV array configurations under partial shading conditions. Renew. Sustain. Energy Rev. 2017, 77, 875-889. [CrossRef]

19. Karagöz, M.K.; Demİrel, H. A Novel MPPT Method for PV Arrays Based on Modified Bat Algorithm with Partial Shading Capability. Int. J. Comput. Sci. Netw. Secur. 2017, 17, 61-66.

20. Belhachat, F.; Larbes, C. A review of global maximum power point tracking techniques of photovoltaic system under partial shading conditions. Renew. Sustain. Energy Rev. 2018, 92, 513-553. [CrossRef]

21. Khanam, J.J.; Foo, S.Y. Modeling of a Photovoltaic Array in MATLAB Simulink and Maximum Power Point Tracking Using Neural Network. J. Electr. Electron. Syst. 2018, 7, 1-8. [CrossRef]

22. Yap, K.Y.; Sarimuthu, C.R.; Lim, J.M.Y. Artificial Intelligence Based MPPT Techniques for Solar Power System: A review. J. Mod. Power Syst. Clean Energy 2020, 8, 1043-1059. [CrossRef]

23. Ahmed, J.; Salam, Z. An Enhanced Adaptive P\&O MPPT for Fast and Efficient Tracking Under Varying Environmental Conditions. IEEE Trans. Sustain. Energy 2018, 9, 1487-1496. [CrossRef]

24. Ahmad, R.; Murtaza, A.F.; Sher, H.A. Power tracking techniques for efficient operation of photovoltaic array in solar applicationsA review. Renew. Sustain. Energy Rev. 2019, 101, 82-102. [CrossRef]

25. Kumar, J.; Rathor, B.; Bahrani, P. Fuzzy and P\&O MPPT techniques for stabilized the efficiency of solar PV system. In Proceedings of the 2018 International Conference on Computing, Power and Communication Technologies (GUCON), Greater Noida, India, 28-29 September 2018; pp. 259-264. Available online: https: / / ieeexplore.ieee.org/document/8674909 (accessed on 10 August 2021). [CrossRef]

26. Andrew-Cotter, J.; Uddin, M.N.; Amin, I.K. Particle Swarm Optimization based Adaptive Neuro-Fuzzy Inference System for MPPT Control of a Three-Phase Grid-Connected Photovoltaic System. In Proceedings of the IEEE International Electric Machines \& Drives Conference (IEMDC), San Diego, CA, USA, 12-15 May 2019; pp. 2089-2094.

27. Rajavel, A.; Rathina Prabha, N. Fuzzy logic controller-based boost and buck-boost converter for maximum power point tracking in solar system. Trans. Inst. Meas. Control 2021, 43, 945-957. [CrossRef]

28. Leite, A.C.Q.B.; Salazar, A.O.; Carvalho, J.T. Maximum power point tracker based digital one cycle control applied in PV systems. Renew. Energy Power Qual. J. 2017, 1, 239-244. [CrossRef]

29. Villalva, M.G.; Gazoli, J.R.; Filho, E.R. Comprehensive approach to modeling and simulation of photovoltaic arrays. IEEE Trans. Power Electron. 2009, 24, 1198-1208. [CrossRef]

30. Bayhan, H.; Bayhan, M. A simple approach to determine the solar cell diode ideality factor under illumination. Sol. Energy 2011, 85, 769-775. [CrossRef]

31. Simon, M.; Meyer, E.L. Detection and analysis of hot-spot formation in solar cells. Sol. Energy Mater. Sol. Cells 2010, 94, 106-113. [CrossRef]

32. Masters, G.M. Renewable and Efficient Electric Power Systems; Wiley-Interscience, John Wiley \& Sons: Hoboken, NJ, USA, 2004; ISBN 3175723993.

33. Yingli Solar Datasheet YGE 60 Células Série 2; Yingli Green Energy do Brasil, S.A.: Brazil 2015, 2. Available online: https:/ /www. neosolar.com.br/loja/fileuploader/download/download/?d=0\&file=custom\%2Fupload\%2FFile-1438699024.pdf (accessed on 6 April 2021).

34. Lappalainen, K.; Manganiello, P.; Piliougine, M.; Spagnuolo, G.; Valkealahti, S. Virtual Sensing of Photovoltaic Module Operating Parameters. IEEE J. Photovolt. 2020, 10, 852-862. [CrossRef] 
35. Spagnuolo, G.; Lappalainen, K.; Valkealaht, S.; Manganiello, P. Photovoltaic Module Parametric Identification. In Proceedings of the 2019 International Conference on Clean Electrical Power (ICCEP), Otranto, Italy, 2-4 July 2019; pp. 302-305. [CrossRef]

36. Karatepe, E.; Boztepe, M.; Çolak, M. Development of a suitable model for characterizing photovoltaic arrays with shaded solar cells. Sol. Energy 2007, 81, 977-992. [CrossRef]

37. Vieira, R.G.; Dhimish, M.; de Araújo, F.M.U.; Guerra, M.I.S. PV module fault detection using combined artificial neural network and sugeno fuzzy logic. Electronics 2020, 9, 2150. [CrossRef]

38. Gupta, A.; Chauhan, Y.K.; Pachauri, R.K. A comparative investigation of maximum power point tracking methods for solar PV system. Sol. Energy 2016, 136, 236-253. [CrossRef]

39. Lamamra, K.; Batat, F.; Mokhtari, F. A new technique with improved control quality of nonlinear systems using an optimized fuzzy logic controller. Expert Syst. Appl. 2020, 145, 113148. [CrossRef]

40. Meharrar, A.; Tioursi, M.; Hatti, M.; Boudghne Stambouli, A. A variable speed wind generator maximum power tracking based on adaptative neuro-fuzzy inference system. Expert Syst. Appl. 2011, 38, 7659-7664. [CrossRef]

41. Kordos, M.; Rusiecki, A. Reducing noise impact on MLP training: Techniques and algorithms to provide noise-robustness in MLP network training. Soft Comput. 2016, 20, 49-65. [CrossRef]

42. Yahyaoui, I. Advances in Renewable Energies and Power Technologies; Elsevier: Kidlington, UK, 2018; ISBN 9781626239777.

43. Mohamed, S.A.; Tolba, M.A.; Eisa, A.A.; El-Rifaie, A.M. Comprehensive modeling and control of grid-connected hybrid energy sources using MPPT controller. Energies 2021, 14, 5142. [CrossRef] 